\title{
Fælles orientering som ressource for idéudvikling: \\ En single case-analyse baseret på Distributed Cognition (DC) \& Conversation Analysis (CA)
}

BRIAN L. DUE

\begin{abstract}
Denne artikel viser, hvordan deltagere på idéudviklingsmøder i danske organisationer skaber fremdrift og fælles forståelse i idéudviklingsprocessen via en række lokale semiotiske ressourcer. Artiklen trækker på Distributed Cognition (DC) (Hutchins 1995) som en teoretisk baggrundsforståelse for, hvad der konstituerer et aktivitetssystem, og anvender multimodal Etnometodologisk Conversation Analysis (EM/CA) som konkret analysemetode. Artiklen bidrager dels med ny viden om, hvordan idéer kognitivt er indlejret i idéudviklingshandlingerne og dels hvordan idéer skabes sekventielt, simultant og multimodalt. Herunder hvordan "konceptuelle formulationer" udtrykker fælles orientering og dermed er en ressource for idéudviklingen. Artiklen eksemplificerer også, hvordan DC og EM/CA sammen kan anvendes analytisk.
\end{abstract}

EMNEORD: Multimodalitet, EM/CA, distribueret kognition, idéudvikling, kreativitet

Når medarbejdere idéudvikler, er de ofte orienteret imod at være "tunet ind" på hinanden. Ligesom en radio kan være eller ikke være tunet ind på en kanal, kan man måske også metaforisk sige, at medarbejdere nogle gange har hul igennem til gensidig forståelse, mens det andre gange ikke er tilfældet. Forståelse imellem mennesker og intersubjektivitet og socialitet $\mathrm{i}$ det hele taget er et yderst komplekst teoretisk spørgsmål med mange forskellige tværdisciplinære positioner (se fx Enfield og Levinson 2006; Enfield 2014). Artiklen vil i den forbindelse 
anvende to forskellige distinkte perspektiver (DC og EM/CA) som værktøjer til at vise, hvordan fælles orientering er en interaktionel og kognitiv ressource under idéudvikling.

I artiklen fokuseres på, hvordan deltageres falles orientering ("joint attention" (Kidwell og Zimmerman 2007)) imod et hypotetisk forestillet scenarie ude i fremtiden (en idé) er en interaktionel og kognitiv ressource. En ressource, der bruges til at udrette idéudvikling in situ, idet deltagere viser ${ }^{1}$ overfor hinanden, at de "tænker på det samme". Anvendelsen af anførselstegn i denne kontekst skyldes, at man aldrig kan vide, om man har de samme indre mentale billeder, som andre har. "At tænke sammen" er derfor et metaforisk udtryk for socialt produceret og synliggjort kognition. De synlige handlinger kan fx være, som artiklen vil vise, bekræftelse af den andens fremsættelser eller fortolkninger samt reproduktion og genbrug med forandring af sproglige og kropslige handlinger (Goodwin under udgivelse).

Dette synlige-for-enhver kommunikative og kognitive arbejde foregår in situ og lokalt (Garfinkel og Sacks 1970). Det gør en minutiøs EM/CA-analyse relevant, idet der fokuseres på, hvordan idéer opstår igennem visning af gensidig forståelse blandt deltagere. EM/CA forstås og anvendes $\mathrm{i}$ denne sammenhæng til at belyse noget om et bestemt udsnit af en økologisk helhed. Og Distributed Cognition (DC) (Hutchins 1995; 2006; 2014) er et perspektiv på, hvordan kognition er indlejret $i$ et distribueret aktivitetssystem på tværs af tid og sted. DC vil analytisk typisk have et samlet menings- eller betydningssystem som udgangspunkt for analyser. EM/CA forstås derimod ikke som en helhedsteori, der gør det muligt at forstå meningsskabelsesprocesser, sprog, kognition, kultur osv. i en helhed, men som en redskabskasse til at forstå den lokale, synlige og accountable ${ }^{2}$ meningsproduktion.

Forståelse knytter sig til de kommunikative mekanismer på samfundsmæssigt og kulturelt niveau, hvor fælles sprog, værdier, erfaringer

1 I EM/CA er det en vigtig teoretisk og metodisk pointe analytisk at orientere sig imod det, deltagere orienterer sig imod ved at vise, at de viser forståelse over for hinanden. På engelsk bruges ordene show eller display. På dansk vil jeg anvende ordene viser, tydeliggør, fremviser og demonstrerer synonymt (Steensig 2015).

2 Ordet account som teoretisk begreb stammer fra Garfinkel (1967), og vi har ikke et godt tilsvarende ord på dansk, hvorfor det engelske anvendes. Accounts er de handlinger mennesker gør for at forklare, hvorfor de gør og siger, som de gør. Det tætteste ord på dansk er nok forklaringsskyldig. 
og historier kan gøre forståelse lettere (Engeström 1999). Men forståelse etableres også på samtalens mikroniveau, hvor måden $\mathrm{fx}$ verbale og non-verbale handlinger designes og responderes på, har stor betydning for, hvorvidt og hvordan der etableres gensidig forståelse in situ via en kompleks tegnproduktion (semiosis; Enfield 2009, Goodwin, C. 2011; Kockelman 2005; Peirce 1955). Den måde fx en taletur eller en kropslig handling udføres på, kan invitere til respons af en bestemt art $\mathrm{i}$ anden-positionen, og førstetaleren kan dermed i en sekventiel tredje position vise, om der er etableret gensidig forstålse ved fx at sige "ja" eller "nej, det var ikke det jeg mente", eller alternativt reparere på budskabet (Schegloff 1997). For eksempel kan en deltager, der fremsætter en idé, tjekke, om samtalepartneren er "tunet ind" på den fremsatte idé, via den måde, han/hun responderer, og kan dermed i tredjepositionen verificere og bygge videre eller reparere på manglende forståelse, hvormed deltagerne kan siges at opbygge et fælles kognitivt forståelsessystem imellem dem.

Ifølge DC er kognition ikke reserveret det enkelte individ, men er en del af et organisme-individ-system. Det er særligt hypotesen om den forlængede bevidsthed (The Extended Mind Hypothesis) (Clark 1997; 2010; 2013; Clark og Chalmers 1998) og teorien om distribueret kognition (DC) (Hutchins 1995; 2006; 2005; 2014; Hollan m.fl. 2000), der er relevante her. Pointen er, at ganske vist foregår neurale processer $i$ hjernen rent fysisk, men kognition forstået som håndtering, konceptualisering, processering, begrebsliggørelse og forståelse af tanker er ikke reserveret til neurale processer i hjernen. De kan ses som distribuerede i og imellem forskellige aktører, ting og netværk, og dermed er de i vid udstrækning - men ikke absolut - socialt iagttagelige. Kognition opstår således i relationen mellem individet og omverdenen i måden miljøet bearbejdes på. Derved er kognition også distribueret i hele systemet af individer og ting på tværs af tid og sted (Hazlehurst m.fl. 2007; Hollan m.fl. 2000).

Artiklen vil i den kontekst særligt fokusere på, hvordan en falles orientering, og dermed evne til at forstå og forudse fx associationsrækker og relevante bidrag til idéudviklingen, er en interaktionel og kognitiv ressource, der bruges til at idéudvikle, og dermed er en funktionel egenskab ved det kognitive aktivitetssystem in situ. Artiklen starter med 
nærmere at diskutere, hvordan EM/CA og DC i de nyeste varianter har et delvist overlap i erkendelsesinteresse om end med forskellige begrebsapparater. Dernæst præsenteres artiklens definition og forståelse af en idé. Så følger en single case-analyse, der viser, hvordan fælles orientering er en ressource for idéudvikling, og endelig afsluttes artiklen med en diskussion af koblingen af EM/CA og DC.

\section{METODOLOGISK GRUNDLAG FOR SAMTÆNKNING AF EM/CA OG DC}

I artiklen tages udgangspunkt i en metodologisk og teoretisk ramme, der samtænker den nyeste udvikling indenfor EM/CA og DC. Det betyder et fokus på den lokale økologi af handlinger og distribueret kognition mellem humane og non-humane aktører in situ. Flere nyere publikationer indenfor multimodal EM/CA (fx Goodwin, C. 2013; Hazel m.fl. 2014; Hindmarsh m.fl. 2014; Ivarsson og Greiffenhagen 2015) og DC (fx Giere 2004; Hazlehurst m.fl. 2007; Jensen 2008; 2014; Pedersen 2012; 2015) har et overlap i fokus på interaktion imellem alle typer aktører, men ud fra forskellige afsæt: hhv. social handling og distribueret kognition og med varierende begrebsapparater og fokusfelter. I denne artikel vil forskelligheder imellem de teoretiske perspektiver ikke blive diskuteret i dybden, men derimod fokuseres der på det komplimentære og frugtbare $i$ at kombinere perspektiverne.

Diskussionen og anvendelsen af DC og EM/CA kan også på et mere generelt niveau ses i lyset af de nyeste diskussioner imellem Distributed Language Approach (DLA) (Cowley 2011) og Dialogisme (Linell 2009). DLA forstås som en videreudvikling af DC, og Dialogisme ses som et paraplybegreb for blandt andet EM/CA. Diskussionen kan ifølge Steffensen (2015: 110 ff.) ses som udspændt imellem tre diskussionspunkter i forhold til 1) hvorvidt man udelukkende bør fokusere på den lokale meningsproduktion in situ eller også kan inddrage en meningsproduktion, der trækker på udefrakommende (historiske og kulturelle) strukturer, 2) hvorvidt man udelukkende bør fokusere på mennesket eller "hele" systemet, og 3) hvorvidt man udelukkende bør fokusere på et enkelt menneske eller menneskers samkonstruktioner og koordineringer. Disse tre diskuteres i det følgende. 


\subsection{Lokal og global meningsproduktion: et udsnit af okosystemet.}

Det er blevet fremført af blandt andet Thibault (2011), at der er forskel på et første-ordens og anden-ordens sprog. Første-ordens sprog er den lokale in situ interaktion, og anden-ordens sprog er de historiske og kulturelle betydninger og forståelser, der aflejres, produceres og reproduceres lokalt ${ }^{3}$. Et anden-ordens sprog kan således kun forstås i lyset af en bredere kontekst af viden, kultur, normer osv. end den lokale ytring og dens sekventielle placering alene. Fokus i DC er generelt på hele systemet af individ-omverden, og således på tværs af niveauer, hvorimod fokus i store dele af EM/CA rent metodisk er på det lokale in situ. Artiklens position er, at mening, betydning og forståelse er yderst komplekst konstitueret via multimodalitet og multiaktivitet samt både historiske og kulturelle fænomener, der går på tværs af tid og rum (Enfield 2009; 2014). Derfor advokeres der også for en etnografisk og kontekst-rig variant af EM/CA (fx Moerman 1988; LeBaron 2008), hvormed relevant kontekst inddrages i analysen. Samtidig fastholdes det, at en adækvat og relevant analyse af et fænomen ikke behøver at beskæftige sig med alt, der konstituerer dette fænomen, da det er potentielt grænseløst. Analytisk er der således fokus på det, som deltagerne gør relevant in situ.

DC har en baggrund i kognition og økosemiotik, der bygger på en biologisk funderet systemteoretisk tilgang (Hoffmeyer 2009; Järvilehto 2009; Steffensen og Fill 2014). EM/CA er omvendt baseret på en mere antropologisk og fænomenologisk tilgang med menneskets handlinger og meningsskabelsesprocesser som omdrejningspunktet (Garfinkel 1967; Sacks 1992). Artiklens position er, at mennesker er organismer i store komplekse biologiske økosystemer som antaget i DC. Men et udsnit af disse større økosystemer kan iagttages som in situ meningsskabelsesprocesser, der har mennesket som fænomenologisk omdrejningspunkt. I artiklen forstås social interaktion og kognition således som udspændt i et økologisk potentielt vidtrækkende aktivitetssystem. Det vil sige, at fx ritualer eller objekter kan have historiske og kulturelle

3 Der synes i denne begrebsbrug at være et vist overlap mellem diskurs med lille-d og Diskurs med store-D (Gee 2010), hvor lille-d er de interaktionelle in situ interaktioner a la EM/CA og store-D er mere makro-strukturer der knytter sig til idehistoriske og kulturelle konstruktioner, som kendes fra poststrukturalismen, fx Foucault. 
betydninger, der går på tværs af tid og sted i distribuerede kognitive systemer. En computer kan fx have brugsmuligheder (affordances; Gibson 1977; Norman 1999), som deltagere har viden om og erfaring med tidligere, og som dermed muliggør visse brugsformer og begrænser andre in situ. Ligeså kan aflejrede kulturelle ritualer som fx måder at være deltager på idéudviklingsmøder gå på tværs af tid og sted men altid blive udført på bestemte måder in situ.

Endelig er både EM/CA og DC stærkt baseret på en kommunikationsteori, der (be)viser hvordan mening altid er en sam-konstruktion (Goodwin 1995), omend fokus og begrebsapparatet er forskelligt (Steffensen 2015).

I artiklen forstås DC som et generelt og konceptuelt perspektiv, der teoretisk indebærer et vidtrækkende system af kognition distribueret i tid, sted og mellem aktører (Hutchins 2006). EM/CA forstås hertil som en specifik metodologi til at analysere interaktioner og anvendelsen af semiotiske ressourcer $i$ bestemte lokale, tidsligt og stedligt bunde aktivitetssystemer (Goodwin 1994; 2007). Der findes så vidt vides ikke en entydig position, der konsistent $\mathrm{i}$ alle dets facetter samtænker EM/ CA og DC. Men arbejde udført af Charles Goodwin (Goodwin og Goodwin 1996; 2000; Goodwin 1994; 2000a; 2000b; 2002; 2007; 2011; 2013) anses i artiklen for at være det helt centrale omdrejningspunkt i dette tværfaglige felt.

\section{2 "At tanke sammen" er en social handling med falles orientering}

Når deltagere handler, som om de "tænker sammen" eller "tænker på det samme", skal det altså ikke forstås bogstaveligt som udtryk for indre mentale tilstande, men som udtryk for, at kognition er distribueret og dermed en del af det komplekse økosystem. "At tænke sammen" kan komme til udtryk som en fælles synlig intentionalitet i idéudviklingsarbejdet (Tomasello og Carpenter 2007). Til forskel fra litteratur, der beskriver, hvordan falles orientering er rettet direkte mod et fysisk objekt (fx Kidwell og Zimmerman 2007) og dermed tydeligvis er fysisk synlig-for-enhver, vil artiklen vise, hvordan fælles orientering mod noget abstrakt og hypotetisk også kan bero på en fælles orientering.

Fælles orientering mod noget hypotetisk og abstrakt er mulig i kraft af et informationsimperativ og et affiliationsimperativ (Enfield 2006). Det 
første betyder, at deltagere kan økonomisere med kognitive handlinger, fordi det kan forudsættes, at samtaledeltagere har tilsvarende grad af viden, forståelse, erfaringer, osv. Det andet betyder, at deltagere som udgangspunkt er orienteret mod at opretholde en tillidsfuld relation. Det er interaktionelt og kognitivt vanskeligt at opnå fælles forståelse om en hypotetisk fremtidig abstrakt idé. Det ses derfor også i data, at deltagere udtrykker og dermed udnytter kognitionens distribuerede karakter til at aflægge (offloade (Dror og Harnad 2008)) noget af forklaringskraften til andet end ord; nemlig kropslige illustrationer og brug af materiel struktur som fx papir og pen (Due 2011; 2012a; 2014a; Nielsen 2012; 2014), hvorved de samtidig gør brug af både informations- og affiliationsimperativet.

I artiklen refereres derfor til Hopp m.fl. (2002) der viser, at de overordnede kriterier for at kunne genkende distribueret kognition må vise sig som en diskussion af synlighed og funktionalitet (jf. også Wittgenstein 1953, Garfinkel 1986):

- Hvad der er distribueret; fx specifik viden, generel viden, personbaseret viden, holdninger/normer/værdier eller historie.

- Hvordan distribution foregår; fx overlap, samtidighed, identiske eller komplementære handlinger, genbrug, kropslige nonverbale handlinger, interaktion med artefakter eller anden materiel struktur.

- Hvem der er inkluderet i distributionen; fx hvem der gør hvilke medlemskategorier relevante ved kun implicit at forudsætte for forståelsen.

\section{HVAD ER EN IDÉ?}

Artiklens udgangspunkt er, at idéer indgår i en intersubjektiv arkitektur, hvor idéerne er kommunikativt designet til at blive hørt og modtaget af andre. Idéer forandrer sig igennem social interaktion via den måde, der tales om idéerne på (Marková m.fl. 2007), og idéerne er ofte fremsat som et bidrag til at løse en given problemstilling. Idéer har således også et fremtidsperspektiv i sig: De omhandler noget, der skal ske på et tidspunkt (Kuhn og Jackson 2008). Idéer er ofte værdiladede beskrivelser, der polariseres som enten gode eller dårlige forslag af deltagerne (Clay- 
man og Reisner 1998), og de behandles ofte som "mere interessante", desto mere overraskende de er (Paulus og Nijstad 2003). Idéudvikling kan derfor forstås som et forslag om, bvad nyt man kan gore i fremtiden for (forbåbentligt) at skabe vardi (jf. Due 2014a). Det er dermed vigtigt at betone, at hvis deltagere behandler handlinger og ytringer om ting, de vil lave i fremtiden, som nye, overraskende og værdifulde forslag in situ, så er der tale om idéer for dem. Om idéerne også er værdifulde for andre, fx ledere eller markedet generelt, er muligt men ikke givet.

Når idéer udtrykkes verbalt og distribueres i lokale aktivitetssystemer, optræder de ofte i metaforer, analogier og forestillinger og behandles ofte som objekter, der kan "tages", "viderebringes", "udvikles", "behandles”, “ejes”, "sælges” osv. (Lakoff og Johnson 1980). Idéer kan fremsættes gennem forskellige handlingstyper fx påstande, konstateringer og ordrer. Men det mest almindelige er handlingstyperne "spørgsmål" og "forslag" (Due 2012b). Som hovedregel er idéer genkendelige som forslag, der kommer til udtryk over flere ture, og kan således overordnet forstås som forslagssekvenser (proposal-sequences (Davidson 1984)).

Idéudviklingsmøder består af deltagere, der taler, bruger deres kroppe og ofte også artefakter som computere, papir, post-its, skriveredskaber, osv. Sprog, krop og ting anses som de tre overordnede tegnsystemer/modaliteter, der har en funktion via en symbolsk mediering (som fx sproget, som deltagere kender via konventioner) og/eller via en indeksikalsk mediering (som fx kroppen eller brug af ting, der skaber en lokal meningsfuld indeksikalsk reference til det, der sker lige nu-og-her), og / eller via fx en kropslig ikonisk gengivelse af en ting, fx håndtegning i luften af en kasse (Peirce 1955; 1991). Dette udgør derfor samlet set en interesse i multimodalitet forstået som deltagernes brug af forskellige semiotiske ressourcer, der er samlet i betydningspakker (Deppermann 2013 Stivers og Sidnell 2005; Streeck, Goodwin og LeBaron 2011).

Megen eksisterende forskning i kreativitet og idéudvikling er udført ud fra et forretningsmæssigt og psykologisk fagfelt. Her anlægger man typisk en funktionalistisk eller en rent kognitiv tilgang ud fra eksperimentelle eller stærkt deduktive metoder (se diskussion i Due 2012b). Typisk er forskningen også formuleret i normative vendinger, der be- 
skriver, hvordan deltagere skal være åbne og "tænke ud af boksen", uden nærmere at forklare, hvad det betyder (fx Vance ogog Deacon 1995). I modsætning til denne type forskning anlægges i denne artikel et metodisk fokus på multimodale handlinger under idéudvikling. Forskningsresultater herfra peger på, hvordan idéudvikling ikke er en sort mystisk boks, men naturligt indlejret i samtalesystemet og derfor beskriveligt i detaljer (fx Heinemann m.fl. 2009, Matthews 2009, Heinemann m.fl. 2012).

\section{DEN EMPIRISKE RAMME}

Analysen vil vise, hvordan fælles orientering mod et abstrakt hypotetisk scenarie er en interaktionel og distribueret kognitiv ressource for idéudvikling. Dette fænomen er blevet undersøgt gennem analyse af naturligt forekommende videodata. Datakorpus består af 11 videofilmede møder fra tre forskellige organisationer: en NGO, en stor medicinalvirksomhed og en offentlig institution. Mikroetnografiske studier blev foretaget $i$ de respektive organisationers kommunikationsafdelinger via observationer, feltarbejde og interviews. Idéudviklingsmøder blev filmet og efterfølgende analyseret. Fænomenet, der undersøges i artiklen, er fundet i mange forskellige varianter og emneområder, og er til stede flere gange under de filmede møder - dog med den forskel, at der er stor variation i, hvor gode medarbejdere er til at udvikle og "tænke sammen med hinanden".

For at kunne vise fænomenet i sin helhed og kompleksitet, er det nødvendigt med en længere detaljeret single case-analyse. Eksemplet stammer fra den offentlige institution. Deltagerne holder et møde, hvor to eksterne konsulenter, med pseudonymerne Chris og Dan, er inviteret med. Det er et idéudviklingsmøde, hvor formålet er at finde og udvikle nye idéer til et arrangement, institutionen skal afholde for gymnasieelever. Det er deltagernes opgave at finde på, hvad der skal ske i løbet af arrangementet. Gruppen har været delt op i to små grupper, men er nu samlet for at fremlægge deres idéer. 


\section{ANALYSE AF EN SINGLE CASE}

Analysen af eksemplet er brudt op i fem underoverskrifter, der fokuserer på situationens kronologiske udfoldelse og hvordan: 1) idéen fremsættes og vurderes, 2) idéen udvikles via en konceptuel formulation, 3) forståelsen af idéen er ulige fordelt og idéen kritiseres, 4) idéen kritikhåndteres, og 5) idéen udvikles via nye konceptuelle formulationer.

Formulationer er velbeskrevne i CA-litteraturen og betyder oprindeligt deltagernes evne til at formulere eller reformulere, hvad der tidligere er blevet sagt, for derved blandt andet at vise forståelse for dette (Garfinkel og Sacks 1970). Heritage og Watson (1979) grundlagde et mere systematisk studie af formulationer, hvor de blandt andet viste, hvordan to varianter var normale: 1) en deltager kan opsummere noget af det, en foregående taler har sagt (fx "det du siger er"), eller 2) en deltager kan opsummere, hvad han/hun ser som konsekvenserne af det, en foregående taler har sagt ( $\mathrm{fx}$ "det betyder altså”). Heritage og Watson redegjorde for, hvordan formulationer er sekventielt placeret som en førstepart i en turpar med præference for enighed i den eller de efterfølgende ture. Det vil sige, at hvis en deltager formulerer, hvad der netop er blevet sagt, så er det forventeligt, at samtalepartneren responderer positivt på formulationen i en tredje position.

Analysen af artiklens eksempel vil hertil vise, hvordan en underkategori kan iagttages, nemlig de konceptuelle formulationer. Disse er kendetegnet ved at være en deltagers opsummering af noget af det, en foregående taler har sagt, men på en måde, hvor det foregående opsummeres $i$ et begreb ( $f x$ "det du siger er en mentorordning"). Analysen bekræfter også Heritage og Watsons oprindelige påstand om præference for enighed, hvilket både kommer til udtryk via udtrykt enighed og sanktionering af udtrykt uenighed.

\subsection{Idéen fremsattes og vurderes}

01 Chris: man ku i virkeligheden fo:rstille sig og $\operatorname{det}^{\prime}(\cdot)$

02 og det va:r at hans skov' fik (.) fire gymnasieelever

03 som men†torer det næste halve år ud af det her'= 
I Chris' første tur (1. 1-3) fremsættes en idé om, at Hans Skov Christensen (daværende direktør for DI) skal være mentor for fire gymnasieelever. Idéen fremsættes ved hiælp af et forestillingsformat hvor Chris designer sin ytring som en beskrivelse af et muligt fremtidsscenarie: "man ku i virkeligheden fo:rstille sig" (1. 1). Forestillingsformatet gør det muligt for Chris at frame idéfremsættelsen i et hypotetisk scenarie, hvor intet endnu er besluttet og meget dermed er muligt. Fremsættelsen af idéen om en mentor får umiddelbar respons af Dan i den sekventielle anden-position hvis primære sociale handling er en vurdering af idéen som en "s::uper sjov idé" (1. 4).

\section{BILLEDE 1: VURDERING AF FREMSAT IDE}

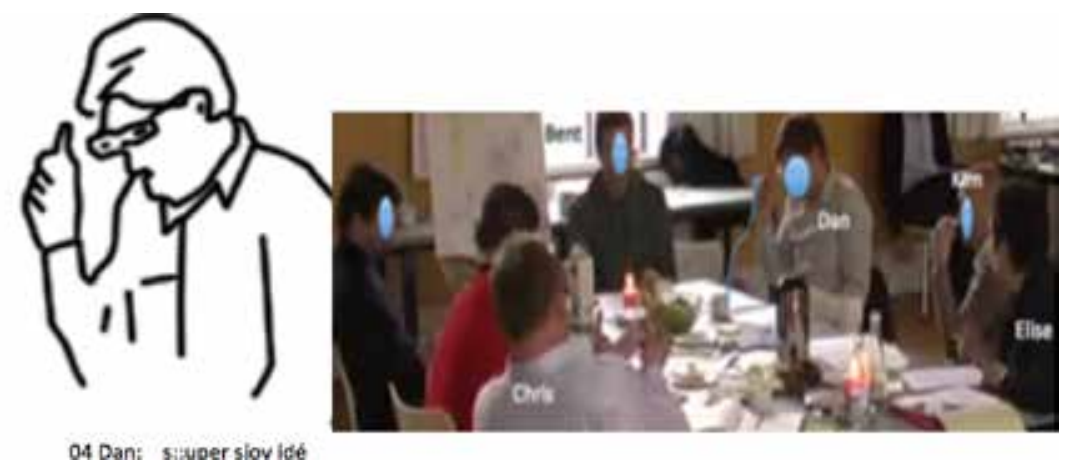

Dans vurdering og eksplicitering af idéen som en "s::uper sjov idé" bliver forstærket af, at han hæver armen og rækker fingeren i vejret, hvor anslagspunktet er sammenfaldende med ytringen. Via den multimodalt udførte vurdering konstruerer Dan således alignment og affiliering (Stivers 2008; Steensig 2013) ${ }^{4}$, dvs. positivt udtrykt orientering mod Chris og den fremsatte idé, hvilket viser et første tegn på udtrykt mulig fælles orientering og forståelse. Denne affilierende vurderingshandling gentages nærmest ordret igen i linje 7 ("god idé"):

4 Affiliation og alignment er engelske termer, der endnu ikke er gode oversættelser af. Alignment er en sekventielt produceret enighed, en ageren i overensstemmelse med den formel-strukturelle oplagte næste handling, $\mathrm{fx}$ at man responderer med minimalrespons og fortsættelsesmarkører som "ja", "hmm", osv. mens den anden taler. Alignment er en markering at at være på linje med den anden, og kan måske oversættes med sekventiel enighed. Affiliation er derimod en mere tydelig positiv og affektiv respons, dvs. en ageren, der ud over den formel-strukturelle handling også adresserer sociale aspekter som fx "super godt, ja, det er en rigtig god idé", osv. Affiliation kan måske oversættes med affektiv enighed. 

ponenter

ud af det her]

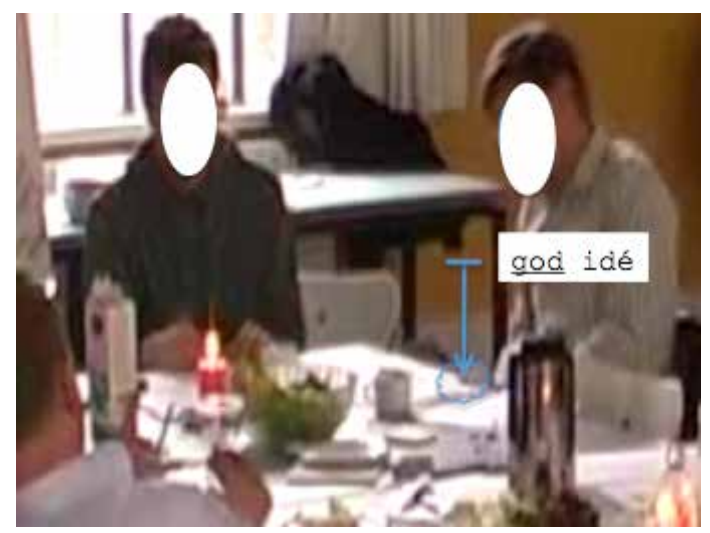

Der optræder her en multimodal vurderings-handling, hvor Dan slår hånden ned $\mathrm{i}$ bordet og anslagspunktet er sammenfaldende med gentagelsen af vurderingen "god idé" (1. 7). Idet hånden rammer bordet, lyder et relativt højt bump, der virker som en forstærkelse af ytringen og dermed budskabet. Handlingen kan således blive begrebsliggjort som en Extreme Case Action Package (ECAP), hvis funktion er at betone talerens budskab (Due 2014b). At sige "god idé" er ikke en Extreme Case Formulation (ECF) (Pomerantz 1986), idet den kraftige betoning ikke ligger i ordvalget men i den simultane inddragelse af håndens slag mod bordet. Derfor er der en semiotisk og systemisk økologi af forskellige sproglige, kropslige og kognitive ressourcer, der er pakket i en samlet kommunikationshandling: Håndbevægelsens funktion er ikke tilfældig, men præcist sekventielt udført som en samlet gestusenhed, hvor forberedelsen, anslaget og tilbagetrækningen følger tempoet og strukturen $\mathrm{i}$ 
ytringen (jf. Kendon 2005). På den måde bruger Dan håndbevægelsen og det nære materielle miljø som materielle og kropslige ressourcer til at gøre handlingen: vise affiliation via multimodale handlinger i et kognitivt distribueret aktivitetssystem. Via de forskellige semiotiske ressourcer distribuerer Dan kognition, hvilket gør det muligt for andre at udvikle videre på idéen, hvilket sker i de efterfølgende ture.

\subsection{Idéen udvikles via en konceptuel formulation}

På baggrund af Dans affilierende respons udvikler Chris idéen videre. Han forklarer, at man kan "gribe syv ud af tredv $\downarrow$ e: elitefolk" (1. 10), der får "nogle opponenter" (1. 11).

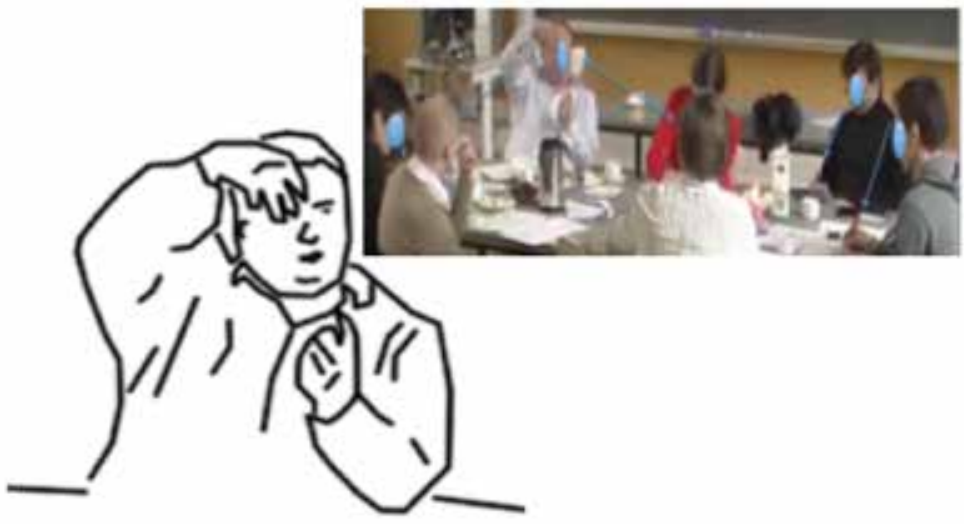

10 Chris: simpelthen gribe syv ud af tredv $\downarrow$ e: elitefolk

Chris handling i linje 10 kan nok ses som en konkretisering af idéen, der er designet ved hjælp af multimodale ressourcer og kropsligt distribueret kognition. Chris udtrykker, at man kan "gribe" nogle elitefolk (tidligere eksemplificeret ved Hans Skov). Mens han siger "gribe", holder han hænderne frem foran sig og laver en bevægelse, hvor han visuelt med den ene hånd tager noget op fra den anden hånd. Ved at bruge hænderne på denne måde viser han formentlig, hvordan nogle få skal "håndplukkes" ud af en større mængde. Denne kropslige illustration gør det muligt for de andre at indgå i en fælles orientering ikke 
"bare" mod idéen som en abstrakt sproglig beskrivelse, men som en kognitivt distribueret kropsliggørelse af idéen. Den multimodale handling kommer dermed til at fungere som visuel illustration og som et kropsliggjort forestillingsrum (Haviland 2000), der er tilgængeligt for alle som fælles orienteringspunkt i det kognitive aktivitetssystem. Chris kognitive forståelsesproces er ikke alene udtrykt visuelt via de kropslige ressourcer, men bliver dermed også samtidig, fordi det netop er synligt-for-enhver, et fælles grundlag for alle andre i et kognitivt distribueret system. På den måde udvikles idéen via forskellige kropslige og verbale ressourcer. Dan responderer på Chris’ idé med en konceptuel formulation, der på samme tid udviser forståelse og bekræftelse af idéen. Han siger: "jo det er en mentorordning [det der ]" (1. 13).

11 Chris:

12 Dan:

13 Dan:

14 Chris :

15

og så fik de i virkelig[heden] nogle opponenter $=$

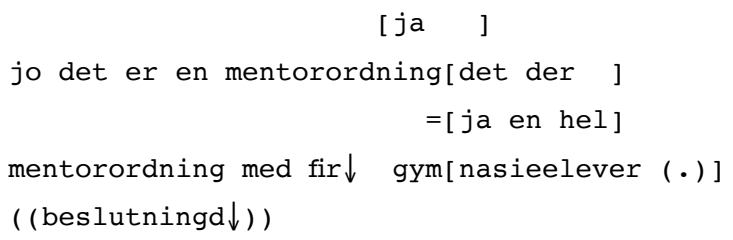

Dans ytring i linje 13 er designet som en formulation, der refererer til Chris' tidligere tur, hvor ordet "mentor" også blev brugt (1. 3). Her er dermed også tale om genbrug på en ny måde ("reuse with transformation" (Goodwin udkommer)). Formulationen repræsenterer udvalgte elementer af alle de foregående ture og samtidig opsummerer og kondenserer formulationen essensen af idéen - med Dans genbrug af ord. Hans opsummering og kondensering (1.13) bliver bekræftet af Chris der responderer præfereret med et ekkoo-format (Svennevig 2003): "ja en hel mentorordning" (1. 14-15).

Formulationen, genbruget og bekræftelsen viser, at Dan og Chris har en form for fælles orientering i et kognitivt distribueret forståelsessystem. Det vil sige, at de synligt-for-enhver viser, at de "tænker det samme" om idéen. På den måde er deres handlinger en aktiv del af deres tænkning, og kognitionen er derved hverken alene noget indre eller blot en egenskab i den enkelte. I formulations-sekvensen (1. 13-14) ses det ved, at Dan genbruger Chris' ord om "mentor" (1. 3) i 
en ny ordkonstruktion ("mentorordning" 1. 13), hvorefter Chris selv $i$ en tredjeposition adopterer den nye ordkonstruktion ("mentorordning" 1. 15) og derved implicit bekræfter relevansen og "rigtigheden" af formulationen. "Rigtigheden" i den forstand, at Chris i det øjeblik adresserer idéen med samme genbrugte ordvalg, hvilket således viser sig som et fælles distribueret indhold og en fælles forståelse af idéen i det lokale aktivitetssystem.

Man kan kalde formatet for en konceptuel formulation, fordi dens funktion ikke blot er at opsummere men også at kondensere pointen i et begreb eller en navngivning, der genbruger tidligere indhold på en ny måde. I dette tilfælde navngivningen: mentorordningen. Denne type formulation er konceptuel i den forstand, at formulationen samler op på tidligere indhold i en begrebsliggørelse, der kan ses som en kognitiv økonomisering, der gør det muligt for deltagerne at etablere en fælles platform (common ground) de kan tale videre ud fra - eller et stillads (scaffolding (Clark 1997)), idéudviklingen kan stå på. Ved at begrebsliggøre idéen ved hjælp af den konceptuelle formulation, som den hidtil er udformet, frisættes kognition til videre udvikling og behandling af idéen - samtidig med at der skabes fælles affiliation og alignment. Men selvom den konceptuelle formulation har den funktion, er det ikke givet at alle er enige. Den næste del af analysen viser, hvordan kritik af idéen udrettes.

\subsection{Idéen kritiseres og fungerer som katalysator}

Efter idéen er blevet præsenteret, opstår der en mindre ekskurs, hvor en deltager fortæller en historie. Disse minutter er ikke inkluderet her. Ved færdiggørelsen af historiefortællingen spørger Bent, der er kommunikationschefen og under det meste af mødet påtager sig rollen som facilitator, hvad Kim tænker om den fremsatte idé. Kim retter kritik mod idéen fra linje 20.

I linje 20-22 holder Kim fokus på, hvordan organisationens forskere kan komme i spil. Et fokus, han ikke mener er til stede i den fremsatte idé. Det gør han via en samlet multimodal handling, hvor han samtidig med ytringen peger på papiret foran sig og kigger ned, hvilket også får Dan til at kigge ned på papiret. I anslagspunktet, hvor Kim siger 


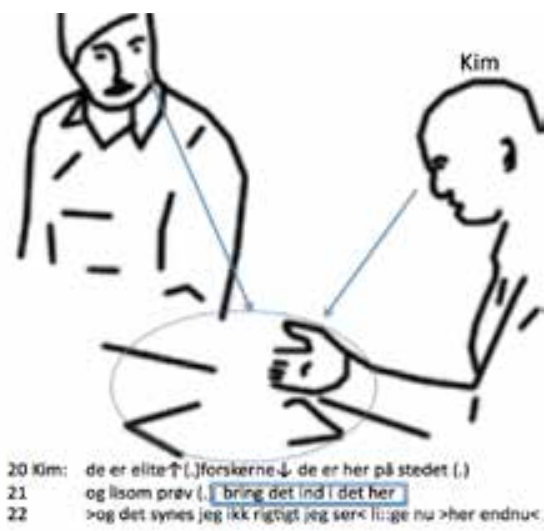

"det her" (1. 21), slår han ud med hånden mod papiret, der således opnår indeksikalsk mening som en materialiseret beskrivelse af idéen ud fra Kims noter på hans papir. Kims kritiske argument er dermed ikke alene sprogligt udrettet men distribueret i det lokale aktivitetssystem, hvor en del af det kognitive og interaktionelle arbejde er udrettet via de materielle og kropslige ressourcer, nemlig at gøre noterne på papiret til en aktør i situationen, hvortil kognitivt indhold er distribueret.

Kims kritik peger på en manglende sammenhæng mellem den opgave, gruppen har fået stillet på workshoppen, og den fremsatte idé. Hvor Chris og Dan producerer affilierende samtænkningsmarkører og udvikler videre på hinandens pointer, udtrykker Kim uenighed eller uforståelighed overfor idéen. Kims kritik er interessant i lyset af formulationernes generelle præference-regel om at blive mødt med enighed, som fremført af Heritage og Watson (1979). Kim responderer ikke præfereret og aligner ikke med idéen som hidtil fremført. Kims ikke-præfererede og disalignede kritik bliver efterfølgende af Chris og Dan behandlet som et interaktionelt problem og sanktioneret via kritikhåndtering.

Netop kritikhåndtering kan således også ses som et argument for, at formulationer, herunder konceptuelle formulationer, netop har en præference for enighed. På den måde fungerer kritikken også som en katalysator (Due 2015), der får Chris og Dan til sammen at videreud- 
vikle idéen i et forsvar mod det kritiske angreb. Selvom Kim tilsyneladende ikke er alignet, er han imidlertid stadig en vigtig del af det kognitive aktivitetssystem. Kims kritik fungerer som katalysator for idéudviklingen, men det interessante i Kims kritik er også, at den er et funktionelt bidrag i den samlede proces, der også gør Kim til sammentænkende part. Selvom Kim er kritisk og uforstående for idéen, har han en funktion i systemet i forhold til idéudviklingens progression. Her er formentlig ikke tale om, at Kim påtager sig en bestemt intentionel kritisk rolle for at effektivisere og højne kvaliteten af idéudviklingen - a la rollen som djavelens advokat. Men det er bestemt en praktisk funktion af handlingen, der således også viser sig at have værdi, idet den fremprovokerer yderligere idéudvikling.

\subsection{Idéen kritikhåndteres via falles stand og distribueret kognition}

Bent spørger ind til Kims kritik af idéen (1. 29), og imens gør Dan en visuel markant handling idet han rejser sig op og dermed skaber en forandring i den kontekstuelle konfiguration (Goodwin 2000a).

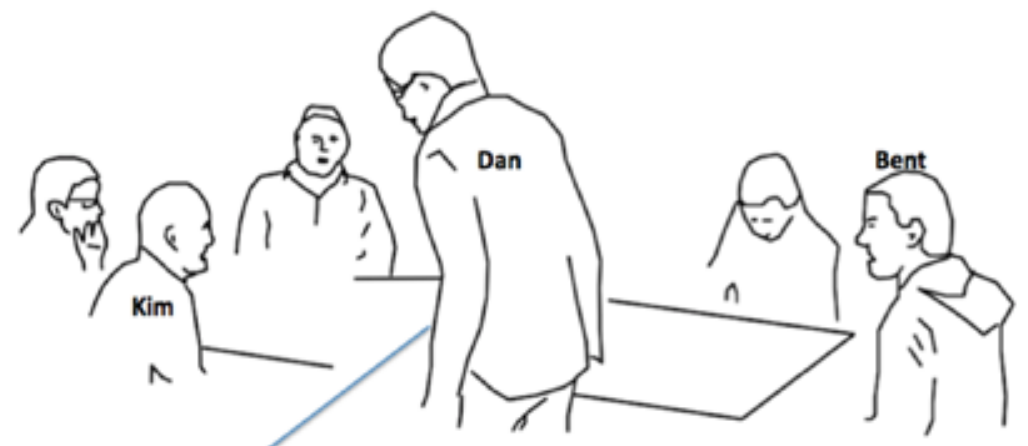

29 Bent: atså hya vill' hva ville vi gøre hvis vi bragte viden i spil

30 (1.3)

31 Kim: vhevhe hvordan vi's: skulle gør det rent konkret tænker du på "hehehe*

Dan rejser sig formentlig for at udrette noget praktisk. Men han bliver stående og tager en kaffekande, der står på bordet foran ham. Den kropslige handling udføres sekventielt tilpasset den lokale kontekst ved at behandle pausen (1. 30) som et overgangsrelevant sted, hvor noget andet kan ske. Dan taler ikke i overlap, og bryder dermed ikke turpar- 
konstruktionen på ytringsniveauet, men han handler kropsligt i overlap ved at rejse sig. Med en kaffekande i hånden kigger han ned på Kim og siger:

BILLEDE 6: DAN STÅR OP OG TALER NED TIL KIM

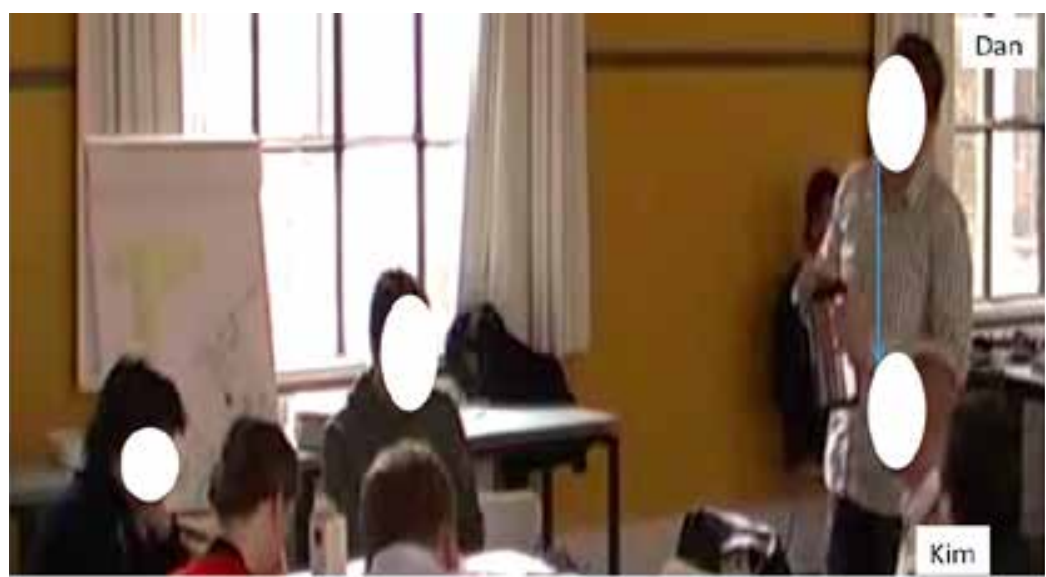

37 Dan: atsá: det tene udelukker jo ikke det andet

38 Kim: nej nej bestemt ikki

Om det var intentionen fra Dan at rejse sig for at "tale ned" til Kim, er ikke til at sige, men det er iagttageligt i situationen, at interaktionen bliver kropsligt asymmetrisk, idet Dan kigger ned på Kim. Dermed modtagerdesigner han kropsligt ytringen (1. 37) som en respons på Kims idékritik. Det sker samtidig ved, at han adresserer Kims tidligere tur ud fra partiklen "det", der implicit refererer til en fælles viden om samtaleemnet som to forskellige elementer, henholdsvis "det ene" og "det andet" (1. 37).

At det er Dan og ikke Chris, der ellers først fremsatte idéen, som præsenterer det første kritikhåndteringsformat, kan måske ses som udtryk for, at Dan og Chris nu orienterer sig synligt-for-enhver affilierende mod hinanden $i$ en polarisering mod resten af deltagerne, eller i hvert fald mod Kim. Man kan derfor tale om, at de allierer sig eller "aligning as a team" (Kangasharju 1996). Som Kangasharju har vist, sker det typisk i situationer, hvor der er potentiel konflikt. Deltagere med samme overbevisning rykker tættere sammen og viser hinanden og andre fællesskab ved at stå sammen om enslydende budskaber. Tænkningen om idéen er dermed distribueret i det lokale aktivitetssystem mellem Dan 
og Chris. Det bliver også klart, idet Chris adresserer den forskel, som Dan tidligere benævnte som "det ene" og "det andet". Chris ekspliciterer nemlig de to elementer, der var de tavse forudsætninger i Dans ytring:

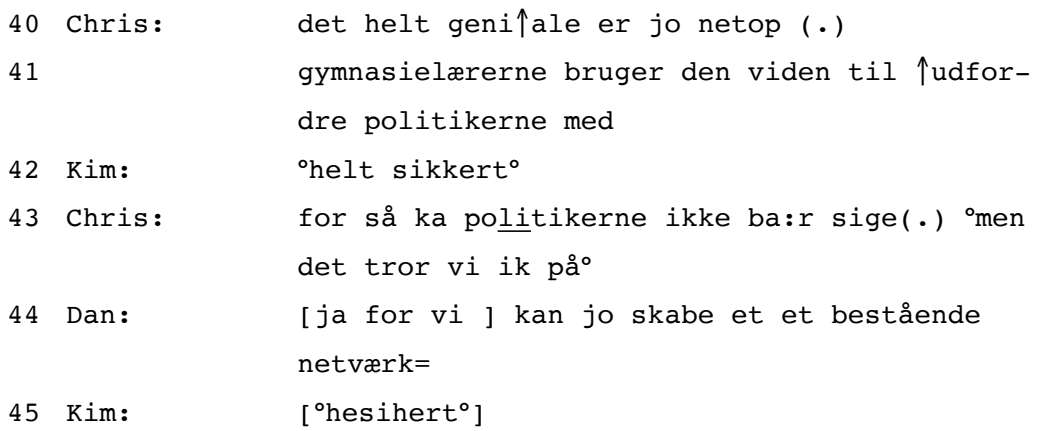

Chris bekræfter og ekspliciterer det, der formentlig også var Dans pointe, nemlig at Kim fremstillede en falsk modsætning mellem universitetets viden ("viden" l. 41) og idéen om en mentorordning ("udfordre politikerne med" (1. 41)). Denne kobling mellem politikerne ("det ene") og forskernes viden ("det andet") har ikke været ekspliciteret før, men har dog været berørt af Bent i linje 29: "hva ville vi gøre hvis vi bragte viden i spil?”' (jf. figur 1).

FIGUR 1: OVERSIGT OVER LIGNENDE ELEMENTER I HHV. CHRIS, DAN OG BENTS YTRINGER

\begin{tabular}{|l|l|l|}
\hline \multicolumn{1}{|c|}{ Chris' ytring } & \multicolumn{1}{|c|}{ Dans ytring } & \multicolumn{1}{c|}{ Bents ytring } \\
\hline "udfordre politikerne med" (1. 41) & det $\uparrow$ ene (1. 37) & bringe "i spil?" (1. 29) \\
\hline forskernes "viden". (1. 41) & det andet (1. 37) & "viden" (1. 29) \\
\hline
\end{tabular}

For Dan og Chris har forståelsen af "det ene og det andet" formentligt været et tavst orienteringspunkt i deres idékonstruktion. De handler, som om forskellen mellem "det ene og det andet" er en uproblematisk og indforstået selvfølgelighed $\mathrm{i}$ idéen, der først bliver ekspliciteret, idet idéen møder kritik. Det skyldes måske, at de to har en fælles type viden og kompetence $i$ et distribueret kulturelt-kognitivt økosystem, hvor de er vant til at arbejde med idéudvikling i organisatoriske kontekster. 
Deres kognitivt distribuerede forståelse af idéudviklingsprocessen og idéen bygger måske på en ens type kulturel segmentering, idet de begge er eksterne konsulenter, der lever af at indgå $i$ kreative processer. Samtidig har de lav forpligtelse over for organisationen, fordi de netop er eksterne konsulenter. Denne udefrakommende og professionelle kompetence er en ressource for idéudviklingen mellem netop de to in situ. Samtidig åbner det også op for en anden type diskussion i forhold til denne proces, hvormed de interne medarbejdere, der har ansvar for projektet, bliver kørt ud på et sidespor. Denne diskussion skal dog ikke yderligere forfølges her.

At Chris og Dan har en fælles orientering viser sig også ved Dans affilierende bekræftelse. Han siger "[ja for vi ] kan jo skabe et et bestående netværk=" (1. 44). Her sker to ting. For det første viser Dan, at han er enig i Chris' kritikhåndtering og italesættelse af "det ene" (mentorordningen) og "det andet" (viden) via den første bekræftende responspartikel "ja". For det andet tilføjer han et nyt element til idéen, nemlig at der skal skabes "et bestående netværk". Derved er turen designet til at vise enighed og forståelse for Chris' kritikhåndtering.

\subsection{Ideen udvikles via nye konceptuelle formulationer}

Chris og Dan er alignet, og de udviser affilation mod hinanden; de to med resten af gruppen som tilskuere. Deres fælles orientering kommer i de næste ture igen til udtryk i anvendelsen af konceptuelle formulationer. Dan foretager videreudviklingen i linje 46-48, stadig stående og med front mod Chris.

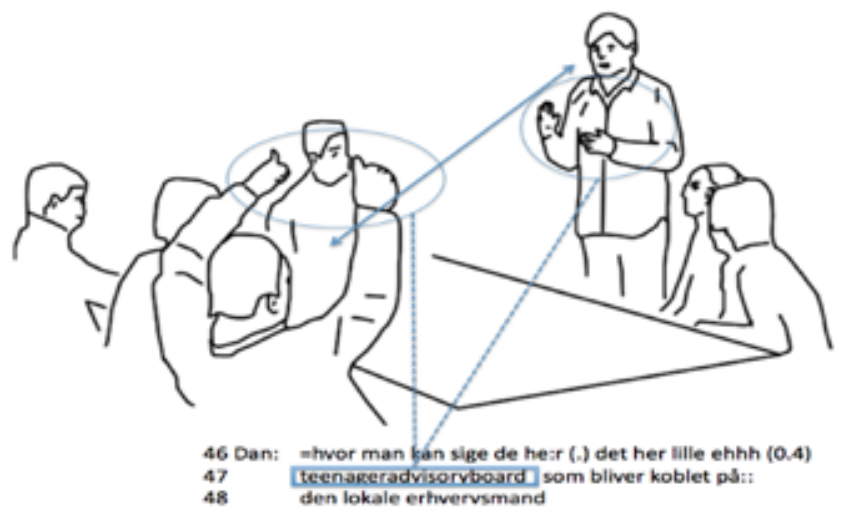


Videreudviklingen og introduktion af det nye ord "teenageradvisoryboard" (1. 47) bliver umiddelbart vurderet af Chris, der udviser kropslig affiliation: Chris rækker hænderne op i luften og strækker tommelfingrene ud, mens han kigger over mod Dan. Anslagspunktet for den kropslige handling er i det øjeblik Dan siger "teenageradvisoryboard". Men den kropslige handling er forberedt med hænderne på vej op, mens Dan taler i linje 46. Den kropslige respons-handling er altså undervejs før Dan producerer den konceptuelle formulation i linje 47. Det peger på, at der sker en koordinering, der relaterer sig til den kropslige sensitivitet og synkrone sam-konstruktion, der udspiller sig mellem Chris og Dan. Dan er allerede på vej til at bekræfte Chris konceptuelle formulation, før den faktisk bliver produceret, hvilket peger på, at det sekventielle system langtfra er eneste gældende menings-horisont. Synkronicitet og simultanitet er i spil og medvirkende som funktionelle elementer i aktivitetssystemet. Sprogliggørelsen af idéen følger en smule forskudt i forhold til den kropslige bekræftelsessekvens (løftede tommelfingre). Det peger på, at den distribuerede kognition kommer synligt til udtryk som en forventning om, at de to (Chris og Dan) "tænker sammen" og har en fælles orientering, førend ytringen er produceret.

Ordet "teenageradvisoryboard" (1. 47) synes således på samme måde som ordet "mentorordning" at fungere som en konceptuel formulation, der opsummerer og kondenserer konstruktionen af idéen ved at begrebsliggøre og dermed skabe et fælles fundament (scaffold). Ordvalget, hvis rigtighed bekræftes og accepteres som en relevant beskrivelse i næste tur (1. 51): "زjepso", har således karakter af at være en kognitiv økonomisering, der igen skaber et fundament bestående af akkumuleret og nu tavst vedtaget viden; en fælles common ground.

49 Dan:

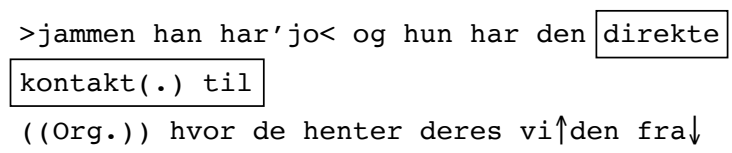

50

${ }^{\circ}$ jeps ${ }^{\circ}$

Efter Chris har responderet med den affilierende markør ved at sige "زeps" (1. 51), udvikler Dan videre på idéen ud fra den nu ekspliciterede dikotomi mellem gymnasieelever, der får viden fra forskere på 
den ene side og erhvervslivet på anden side ("det ene" vs. "det andet", jf. figur 1). Videreudviklingen består i, at han introducerer endnu et nyt element til idéen "vidensmæssige gatekeepere" (1. 54), der bliver kropsligt vurderet i næste (kropslige) sekventielle position.

\begin{tabular}{|c|c|}
\hline 2 Dan: & $\begin{array}{l}\text { det vil si:ge (.) et et'landet sted så ka: } \downarrow \\
\text { så ka: : }\end{array}$ \\
\hline 3 & $(0.4)$ \\
\hline 4 & 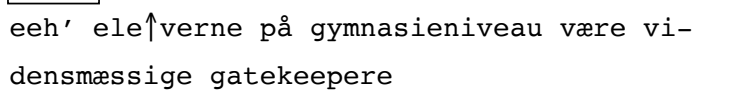 \\
\hline & $\begin{array}{l}\text { i } \uparrow \text { forhold til det er de tunge[erhvervs]folk } \\
(\cdot)=\end{array}$ \\
\hline
\end{tabular}

BILLEDE 8: KROPSLIG ENIGHEDSMARKØR

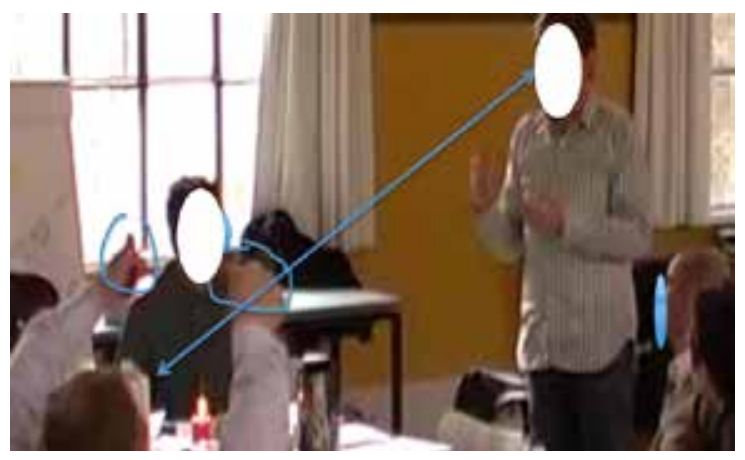

Dan producerer en pause i linje 53 og en kort ordsøgning (1. 54) før han introducerer idéen om at gymnasieeleverne skal være "vidensmæssige gatekeepere" (1. 54) - hvilket også kan forstås som en konceptuel formulation, der begrebsmæssigt opsamler og genbruger tidligere indhold og indrammer idéen. Chris responderer i kropsligt overlap ved igen (kropsligt genbrug) at hæve hænderne og strække tommelfingrene ud, hvilket i situationen virker som en alignet og affilierende enighedsmarkør, der tydeligt indikerer kropsliggjort og distribueret kognition.

Den kropslige markering viser sig som en sekventielt tilpasset vurdering og bekræftelse af, at Chris er enig i Dans budskab. Ud over den kropslige markering italesætter Chris også sin enighed som be- 
kræftende overlappende tale i linje 56, hvor han siger " [ ${ }^{\circ}$ exactly ${ }^{\circ}$ ". Chris' kropsliggjorte og italesatte kognitivt distribuerede vurdering og bekræftelse af Dans taletur optræder som et overlappende simultant fænomen, hvor en del af det kognitive arbejde er udstrakt i det lokale aktivitetssystem, distribueret i sprogligt genbrug og kropslige illustrationer. Ud fra, hvordan Chris responderer på Dans idéudvikling, ses det, hvordan han affilierer med Dan i en fælles distribution af idéens elementer.

\section{DISKUSSION AF FÆLLES ORIENTERING SOM EN RES- SOURCE}

Den præsenterede analyse af idéudviklingssekvensen viser, hvordan en fælles multimodal og kognitivt distribueret orientering imellem to deltagere er udspændt $\mathrm{i}$ et lokalt aktivitetssystem, samt hvordan deltagerne skaber og udvikler idéen sekventielt og simultant. Ikke alle deltagerne aligner i denne idéudvikling, men idékritikken virker som katalysator for videreudviklingen af idéen.

Enfield (2006: 399) pointerer, at: "common ground affords economy of expression", hvilket i eksemplet blandt andet viser sig ved deltagernes genbrug af indhold (sprog, krop) og produktionen af konceptuelle formulationer. Pointen er, at de to deltagere er i stand til at aktivere en række betragtninger, der gør idéudviklingen til en proces, der forløber, uden at hver handling yderligere skal forklares. Dan og Chris' mulige fælles grundlag (socialt, kognitivt, erfaringsmæssigt etc.) gør det muligt for dem at "fange hinandens idéer" og "tænke videre" uden at eksplicitere alle præmisser. Denne kognitive og interaktionelle økonomisering kommer til udtryk på to typer sammenhængende og forbundne måder.

På EM/CA mikroniveau er deres kommunikationshandlinger modtagerdesignede og indgår i en intersubjektiv arkitektur, hvor hvert bidrag behandles som relevant gennem præfererede minimalresponser, selvom der kan iagttages forskydninger og forandringer af ordvalg og betydning. På den måde produceres lokal viden gennem multimodale kommunikationshandlinger, der aktiverer socialt tilgængelige og iagttagelige nye associationsrækker, der er forståelige og interessante for netop Chris og Dan - og tilsyneladende ikke for de andre. På DC sy- 
stem-individ-niveau deler Chris og Dan formentlig en eller anden grad af akkumuleret erfaring og viden om idéudviklingsprocesser på tværs af tid og rum i kraft af deres rolle som eksterne kreative konsulenter. En viden og erfaring, der er distribueret i et kognitivt system med indforstået viden om idéudviklingsprocesser og måder at have "ja-hatten" på i den type processer. Det viser sig, at de to supplerer hinanden med udbygning og udvikling af idéen på en måde, som de begge bekræfter hinanden i (se figur 2-3), uden at de imidlertid bruger de samme formuleringer. Men Chris og Dan behandler ordene/formuleringerne som medlemmer af den samme overordnede metakategori, og de genbruger hinandens indhold med løbende kreative samkonstruerede forandringer (jf. Anward 2015; Goodwin udkommer). Det peger på, at de har en fælles social og kognitiv orientering. Følgende elementer tilføjes fx under udviklingen af idéen:

FIGUR 2: OVERSIGT OVER ELEMENTER, DER TILFØJES IDEEN UNDERVEJS

1. Hans Skov får fire gymnasieelever som mentorer (1. 1-3)

2. Gymnasieeleverne skal følge ham og være opponenter på ham (1. 4)

3. Der må være flere elitefolk: Man må tage syv ud af tredive (1. 10)

4. Der må skabes et bestående netværk (1. 41)

5. Der udfordrer politikerne (1.41)

6. Der skal laves et teenage advisory board (1. 47)

7. Det skal kobles på den lokale erhvervsmand (1. 48)

8. Gymnasieeleverne skal være vidensmæssige gatekeepere (1. 54)

9. I forhold til det tunge erhvervsfolk (1. 55)

Undervejs i eksemplet sker der som vist i figur 2 en udvikling og udfoldelse af idéen, hvor flere elementer tilføjes og indhold genbruges med forandringer. Chris og Dan behandler hinandens bidrag undervejs som relevante udviklinger af idéen. Den fælles orientering har strukturelle egenskaber, der knytter sig til tilstedeværelsen af kroppe med blikke og gestikulationer i et materielt og rumligt semiotisk miljø, hvor Chris 
og Dan behandler hinandens responser som "rigtige" og relevante på følgende måder og ud fra følgende handlingstyper:

FIGUR 3: OVERSIGT OVER HANDLINGSTYPER DER BLIVER UDRETTET UNDERVEJS

\begin{tabular}{|l|l|l|}
\hline $\begin{array}{l}\text { Sekventiel } \\
\text { respons-position }\end{array}$ & $\begin{array}{l}\text { Kommunikations- } \\
\text { handling }\end{array}$ & Handlingstype \\
\hline linje 4 & s::uper sjov idé & Account \\
\hline billede 1 & Dan rejser fingeren & Bekræftelse (projicering) \\
\hline billede 2 & Dan slår i bordet & Bekræftelse \\
\hline linje 7 & det er... god idé & Account \\
\hline linje 13 & det er en mentorordning & Konceptuel formulation \\
\hline linje 14 & ja en hel] mentorordning & Bekræftelse \\
\hline linje 47 & Teenageradvisoryboard & Konceptuel formulation \\
\hline linje 51 & ${ }^{\circ}$ jeps ${ }^{\circ}$ & Bekræftelse \\
\hline linje 54 & "vidensmæssige gatekeepere" & Konceptuel formulation \\
\hline billede 8 & Chris viser tommelfingre $^{\circ}$ & Bekræftelse \\
\hline linje 56 & ${ }^{\circ}$ exactly ${ }^{\circ}$ & Bekræftelse \\
\hline
\end{tabular}

Denne gensidige bekræftelse af hinandens sproglige videreudvikling og genbrug med forandringer kan altså ses som udtryk for fælles orientering og distribueret kognition. Det viser sig mest eklatant ved, at Chris refererer til elitepersonerne som politikere (1. 41) og Dan bagefter til elitepersonerne som erbvervsfolk (1. 48). Denne forskel i reference ser ikke ud til at gøre nogen forskel for de to, hvilket omvendt peger på, at de er orienteret mod overkategorien elitepersoner. De orienterer sig mod hinandens overordnede distribuerede tænkning og har derfor en fælles intentionalitet rettet mod denne medlemskategori.

Det er samtidig en pointe, at idéen netop udvikles in situ, handlingefter-handling, og ikke har et færdigt endemål, selvom de orienterer sig mod et fælles fremtidigt hypotetisk scenarie. Elementer i idéen er selvsagt ikke skabt ud af det blå i situationen, men er indhold, der er trukket på via det større kulturelle kognitive økosystem af betydninger. Referencer til fx mentorordninger, arrangementer for gymnasieelever og direktøren fra DI er bundet til historisk viden og erfaring, der overskrider tid og rum i situationen, men som samtidig anvendes som kognitive ressourcer $i$ situationen. 
Idéen præsenteres og forstås først retrospektivt som en idé baseret på de semiotiske muligheder, der opstår, idet deltagerne interagerer. Der er på den måde tale om en kreativ proces $i$ ordets oprindelige betydning; creare - at skabe. Idéen har ikke en essens eller substans, den af sig selv stræber imod at nå til udfoldelse af, men idéen skabes løbende gennem den multimodale, sekventielle og simultane produktion af handlinger indlejret $\mathrm{i}$ det distribuerede kognitive system, der efterfølgende tilskrives mening gennem reproduktion, genbrug med variation og videreudvikling.

Det gør det også interessant at forholde sig til, hvad der af deltagerne behandles som relevante bidrag, udviklinger og genbrug med forandringer - og hvad der ikke gør. Hvor Chris og Dan behandler hinandens bidrag som relevante og "rigtige" i forhold til en metakategori, behandles Kims bidrag omvendt som "forkert". En idéudviklingsproces viser sig således at have et moralsk niveau og normer for, hvad der er logiske og legitime associationsrækker samt hvad der er mulige forudsigelig handlings-baner (trajectories). Selvom Kims handlinger fx er del af det kognitivt distribuerede aktivitetssystem og har en tydelig funktion som katalysator af den videre idéudvikling, behandles Kims bidrag som forkert. Omvendt behandler Chris og Dan hinandens handlinger som relevante, formentlig fordi de foregriber, hvad der antages at være logiske udviklinger.

Foregribelsen, udtrykt igennem forskellige interaktionelle og kognitive ressourcer, synes altså at være en værdifuld funktion i en idéudviklingsproces, hvor det fælles orienteringspunkt ikke er fx et fysisk objekt, men et abstrakt hypotetisk scenarie.

Et andet lignende krav til forekomsten af fælles orientering som en ressource synes at være metakommunikationen. Metakommunikation er her primært forstået som de tegn og den overordnede distribuerede tænkning, der udgør den øverste medlemskategori, under hvilken variationer håndteres af deltagere. På baggrund af analysen er det nærliggende at tale om, at deltagerne er orienteret imod en metakommunikativ fælles kognitiv framing, og dermed på en eller anden måde "tænker sammen" eller er på "bølgelængde", hvis de er i stand til at:

- færdiggøre hinandens ytringer med samme mening

- kommunikere samme mening synkront eller omvendt forskudt 
- bekræfte kommunikationshandlinger, der umiddelbart forskyder fokus (og dermed "normalt" gør reparatur relevant).

\section{KONKLUSION}

Artiklen har vist, hvordan deltagere indgår i en kognitiv økonomisering, hvor information placeres i en fælles accepteret konceptuel formulation, således at andre kognitive aktiviteter kan gives mere plads. Informationsimperativet (Enfield 2006) betyder, som nævnt i indledningen, at deltagere kan økonomisere med handlinger, fordi det kan forudsættes, at samtaledeltagere har tilsvarende grad af viden, forståelse, erfaringer, osv. Ud over at kognitionen er distribueret og dermed fordelt og økonomiseret, er effekten dermed også en reduktion af kompleksiteten i idéudviklingen. Det vanskelige ved at forestille sig et fremtidigt hypotetisk scenarie, der kendetegner idéudviklingsaktiviteten, opblødes ved at distribuere noget af forklaringskraften til andre tegnsystemer som fx den kropslige illustration orkestreret af en konceptuel formulation. Brugen af ressourcer i det nære miljø fungerer som deltageres kognitive stilladsering, dvs. som støttende hiælpemidler eller et fælles fundament.

På den måde har artiklen også vist, hvordan EM/CA i sin nyeste semiotiske udvikling er metodisk og til en vis grad teoretisk relevant at koble med et DC-perspektiv. Idéudviklingsprocessen er grundlæggende udført i et distribueret netværk af en lang række forskellige tegnsystemer og aktører, der af deltagere sammenkobles og samskabes i lokale økologier. Disse har selvfølgelig vidtrækkende forgreninger, der overskrider tid og rum, og således bygger på deltagernes forståelse af tidligere idéer, tidligere koncepter, der har virket og ikke-virket, tidligere relationer, osv. I forhold til det samlede aktivitetssystem har artiklen fokuseret på det lokalt emergente og har vist, hvordan de kognitive processer i forhold til at forstå og konceptualisere idéer er distribueret imellem deltagerne in situ ved hiælp af en række forskellige multimodale ressourcer.

Sproglige, kropslige og materielle handlinger er ressourcer, der gør fælles orientering mulig $i$ et lokalt og kognitivt aktivitetssystem, mens meningsproduktionen samtidig også altid griber bagud i tid og fremad 
i relevante projiceringer. Artiklen har vist, hvordan fælles orientering kan være en vigtig ressource in situ, men andre mere DC-inspirerede analyser, der kigger på de bredere netværk, ville måske fokusere på handlingers betydning $\mathrm{i}$ et bredere aktivitetssystem. Det ene udelukker ikke det andet, og der er fremadrettet grobund for flere systematiske analyser ud fra DC og EM/CA.

\section{ANERKENDELSER}

Tak til anonyme reviewers for konstruktiv feedback og pointering af vigtige distinktioner og særligt tak til Thomas Wiben Jensen og Simon Biering Lange for værdifulde kommentarer.

Brian L. Due

Institut for Nordiske Studier og Sprogvidenskab

Københavns Universitet

bdue@hum.ku.dk 


\section{LITTERATUR}

Anward, Jan. 2015. Doing language. Linköping University: Electronic Press.

Clark, Andy \& David Chalmers. 1998. The Extended Mind. Analysis 58(1). 7-19.

Clark, Andy. 1997. Being There: Putting Brain, Body, and World Together Again. Cambridge, MA: MIT Press.

Clark, Andy. 2010. Supersizing the Mind: Embodiment, Action, and Cognitive Extension. 1. ed. New York: Oxford University Press.

Clark, Andy. 2013. Mindware: An Introduction to the Philosopby of Cognitive Science. 2. ed. New York: Oxford University Press.

Clayman, Steven \& Ann Reisner. 1998. Gatekeeping in Action: Editorial Conferences and Assessments of Newsworthiness. American Sociological Review 63(2). 178-99.

Cowley, Stephen J. 2011. Distributed Language. Amsterdam: John Benjamins Publishing.

Davidson, Judy. 1984. Subsequent Versions of Invitations, Offers, Requests, and Proposals Dealing with Potential or Actual Rejection. Atkinson, J. Maxwell \& John Heritage. (red.), Structures of Social Action: Studies in Conversation Analysis. 7. ed. (Studies in Emotion and Social Interaction), 102-29.

Deppermann, Arnulf. 2013. Multimodal interaction from a conversation analytic perspective. Journal of Pragmatics 46(1). 1-7.

Dror, Itiel E. \& Stevan Harnad. 2008. Offloading Cognition onto Cognitive Technology. Dror, Itiel E. og Stevan Harnad (red.) Cognition Distributed. Amsterdam: John Benjamins Publishing.

Due, Brian L. 2011. Kroppen som ressource for ideudvikling (The Body as a Resource for Idea Development). Ruben, Jesper \& Jon H. Arnfred (red.), Kroppen i Samfundet, Samfundet $i$ Kroppen. 50-70. Alkvantor.

Due, Brian L. 2012a. Den narrative konstruktion af en idé: En singlecase multimodal analyse af narrativer som ressource for udvikling af nye ideer under møder. Språk og Interaktion 3(8).

Due, Brian L. 2012b. Den sociale konstruktion af ideer (The Social Construction of Ideas). Ph.d.afhandling. Københavns Universitet.

Due, Brian L. 2014a. Ideudvikling. En multimodal tilgang til innovationens kreative faser. København: Samfundslitteratur.

Due, Brian L. 2014b. The development of an idea in a context of rejection. Semiotica 202. 207-39.

Due, Brian L. 2015. Idéudviklingens trepartstruktur og den katalytiske funktion af kritik. Språk och interaktion 4(2).

Enfield, Nicholas J. \& Stephen C. Levinson. 2006. Introduction: Human Sociality as a New Interdisciplinary Field. Enfield, Nicholas J. \& Stephen C. Levinson (red.), Roots of Human Sociality. Berg Press. 
Enfield, Nicholas J. 2006. Social Consequences of Common Ground. Enfield Nicholas J. \& Stephen C. Levinson (red.), Roots of Human Sociality: Culture, Cognition and Interaction. Berg Press.

Enfield, Nicholas J. 2009. The Anatomy of Meaning: Speech, Gesture, and Composite Utterances. Cambridge: Cambridge University Press.

Enfield, Nicholas J. 2014. Causal dynamics of language. Enfield, Nicholas J., Paul Kockelman \& Jack Sidnell (red.), The Cambridge Handbook of Linguistic Anthropology. Cambridge: Cambridge University Press.

Engeström, Yrjö. 1999. Innovative Learning in Work Teams. Engestöm, Yrjö, Reijo Miettinen \& Raija-Leena Punamäki (red.), Perspectives on Activity Theory. Cambridge: Cambridge University Press.

Fauconnier, Gilles \& Mark Turner. 2002. The way we think: conceptual blending and the mind's bidden complexities. New York: Basic Books.

Fauconnier, Gilles. 1997. Mappings in thought and language. Cambridge U.K: Cambridge University Press.

Fauconnier, Gilles. 2001. Conceptual Blending and Analogy. Gentner, Dedre, Keith J. Holyoak \& Boicho N. Kokino (red.), The Analogical Mind: Perspectives From Cognitive Science. 255-85. Massachusetts Institute of Technology.

Garfinkel, Harold \& Harvey L. Sacks. 1970. On Formal Structures of Practical Actions. McKinney, John C. \& Edward A. Tiryakian (red.): Theoretical Sociology. 338-66. Appleton Century Crofts.

Garfinkel, Harold. 1967. Studies in Ethnomethodology. Englewood Cliffs, N. J.

Garfinkel, Harold. 1986. Ethnomethodological Studies of Work. Routledge.

Gee, James P. 2010. An Introduction to Discourse Analysis: Theory and Method. 3 ed. New York: Routledge.

Gibson, James J. 1977. The Theory of Affordance. Shaw, Robert \& John Bransford (red.), Perceiving, Acting, and Knowing. Lawrence Erlbaum Associates.

Giere, Ronald N. 2004. The Role of Agency in Distributed Cognitive Systems. Philosophy of Science 73(5).

Goodwin, Charles \& Marjorie M. Goodwin. 1996. Formulating Planes: Seeing as a Situated Activity. Middleton, David \& Yrjö Engestrom (red.), Cognition and Communication at Work. 61-95. Cambridge University Press.

Goodwin, Charles \& Marjorie M. Goodwin. 2000. Emotion within Situated Activity. Alessandro Duranti (red.), Linguistic Anthropology: A Reader. 239-57. Malden, MA, Oxford: Blackwell.

Goodwin, Charles. (Under udgivelse). Co-Operative Action.

Goodwin, Charles. 1994. Professional Vision. American anthropologist 96(3). 606. 
Goodwin, Charles. 1995. Co-Constructing Meaning in Conversations with an Aphasic Man. Research on Language and Social Interaction 28(3). 233-60.

Goodwin, Charles. 2000a. Action and Embodiment Within Situated Human Interaction. Journal of Pragmatics 32(10). 1489-522.

Goodwin, Charles. 2000b. Practices of Color Classification. Mind, Culture, and Activity 7(1-2). 19-36.

Goodwin, Charles. 2002. Time in Action. Current Anthropology 43(4). 19-35.

Goodwin, Charles. 2007. Participation, Stance and Affect in the Organization of Activities. Discourse and society 18(1). 53-74.

Goodwin, Charles. 2011. Building action in public environments with diverse semiotic resources. Versus: quaderni di studi semiotici 112. 169-82.

Goodwin, Charles. 2013. The co-operative, transformative organization of human action and knowledge. Journal of Pragmatics 46(1). 8-23.

Haviland, John B. 2000. Pointing, Gesture Spaces, and Mental Maps. David McNeill. (red.), Language and Gesture, 13-47. Cambridge University Press.

Hazel, Spencer, Kristian Mortensen \& Gitte Rasmussen. 2014. Introduction: A body of resources - CA studies of social conduct. Journal of Pragmatics 65. 1-9.

Hazlehurst, Brian, Carmit K. McMullen \& Paul N. Gorman. 2007. Distributed cognition in the heart room: How situation awareness arises from coordinated communications during cardiac surgery. Journal of Biomedical Informatics 40(5). 539-51.

Heinemann, Trine, Jeanette Landgrebe \& Ben Matthews. 2012. Collaborating to restrict: a conversation analytic perspective on collaboration in design. CoDesign 8(4). 200-14.

Heinemann, Trine, Robb Mitchell \& Jacob Burr. 2009. Co-constructing meaning with materials in innovation workshops. Darras, Bernard \& Sarah Belkhamsa. (red.), Objecst et communication, 30-31. L'Harmattan.

Heritage, John \& Rodney Watson. 1979. Formulations as Conversational Objects. George Psathas. (red.), Everyday Language. Studies in Ethnomethodology. 123-63 Irvington Publishers.

Hindmarsh, Jon, Lewis Hyland \& Avijit Banerjee. 2014. Work to make simulation work: «Realism», instructional correction and the body in training. Discourse Studies 16(2). 247-69.

Hoffmeyer, Jesper. 2009. Biosemiotics: An Examination into the Signs of Life and the Life of Signs. Reprint edition. Scranton: University of Scranton Press.

Hollan, James, Edwin Hutchins \& David Kirsh. 2000. Distributed cognition: toward a new foundation for human-computer interaction research. ACM Trans. Comput.-Hum. Interact. 7(2). 174-96.

Hopp, Pam, C. Smith \& Stephen C. Hayne. 2002. Literature Review of Shared Cognition. College of Business, Colorado State University, Working Paper.

Hutchins, Edwin. 1995. Cognition in the Wild. [Ma: MIT Press]: http://cognet.mit.edu. 
Hutchins, Edwin. 2005. Material anchors for conceptual blends. Journal of Pragmatics 37(10). $155-77$.

Hutchins, Edwin. 2006. The distributed Cognition Perspective on Human Interaction. Enfield, Nicholas J. \& Stephen C. Levinson (red.), Roots of buman sociality: culture, cognition and interaction. Berg Press.

Hutchins, Edwin. 2014. The cultural ecosystem of human cognition. Philosophical psychology 27(1). $34-49$.

Ivarsson, Jonas \& Christian Greiffenhagen. 2015. The Organization of Turn-Taking in Pool Skate Sessions. Research on Language and Social Interaction 48(4). 406-29.

Jensen, Thomas W. 2008. Kognition i interaktion: den interaktionelle brug af hukommelse og folelser i parterapisamtaler. Ph.d.-afhandling. Københavns Universitet.

Jensen, Thomas W. 2014. Emotion in languaging: languaging as affective, adaptive, and flexible behavior in social interaction. Frontiers in Psychology 5.

Järvilehto, Timo. 2009. The Theory of the Organism-Environment System as a Basis of Experimental Work in Psychology. Ecological Psychology 21(2). 112-20.

Kangasharju, Helena. 1996. Aligning as a Team in Multiparty Conversation. Journal of Pragmatics 26(3). 291-319.

Kendon, Adam. 2005. Gesture: Visible Action as Utterance. Cambridge University Press.

Kockelman, Paul. 2005. The Semiotic Stance. Semiotica 2005(157). 233-304.

Kuhn, Timothy \& Michele Jackson. 2008. Accomplishing Knowledge. Management Communication Quarterly 21(4). 454-85.

Lakoff, George \& Mark Johnson. 1980. Metaphors We Live By. Chicago: University of Chicago Press.

LeBaron, Curtis. Microethnography. 2008. Karen Tracy (Ed.), The International Encyclopedia of Communication. Online through http://www.communicationencyclopedia.com/public/. Blackwell.

Linell, Per. 2009. Rethinking Language, Mind, and World Dialogically: Interactional and Contextual Theories of Human Sense-making. IAP.

Matthews, Ben. 2009. Intersections of brainstorming rules and social order. CoDesign, 5(1). 65-76.

Moerman, Michael. 1988. Talking Culture: Ethnography and Conversation Analysis. Philadelphia: University of Pennsylvania Press.

Nielsen, Mie F. 2012. Using Artifacts in Brainstorming Sessions to Secure Participation and Decouple Sequentiality. Discourse Studies 14(1). 87-109.

Nielsen, Mie F. 2014. Sizing up «the box» in order to fit in. CoDesign 10(2). 112-34.

Norman, Donald. 1999. Affordance, Conventions, and Design. Interactions 6(3). 38-43. 
Paulus, Paul B. \& Bernard A. Nijstad. 2003. Group Creativity: An Introduction. Paulus, Paul B. \& Bernard A. Nijstad (eds.), Group Creativity. Innovation through collaboration, 3-15. Oxford: Oxford University Press.

Pedersen, Sarah B. 2012. Interactivity in health care: bodies, values and dynamics. Language Sciences 34(5). 532-42.

Pedersen, Sarah B. 2015. The Cognitive Ecology of Human Errors in Emergency Medicine - an Interactivitybased Approach. Ph.d.-afhandling. Syddansk Universitet.

Peirce, Charles S. 1955. Philosophical writings of Peirce. New York: Dover Publications.

Peirce, Charles S. 1991. Peirce on Signs: Writings on Semiotic. Chapel Hill: University of North Carolina Press.

Pomerantz, Anita. 1986. Extreme Case formulations: A way of legitimizing claims. Human Studies 9. 219-29.

Sacks, Harvey L. 1989. Lecture Six: The M.I.R. Membership Categorization Device. Human Studies 12(3/4). 271-81.

Sacks, Harvey L. 1992. Lectures on Conversation with an Introduction by Emanuel A. Schegloff. Oxford: Blackwell.

Schegloff, Emanuel A. 1997. Third Turn Repair. Amsterdam studies in the theory and history of linguistic science. Series IV, Current issues in linguistic theory 128. 31.

Schegloff, Emanuel A. 2003. On ESP Puns. Philip J. Glenn \& Curtis D. LeBaron (red.), Studies in Language and Social Interaction, 531-40. Lawrence Erlbaum Associates.

Schegloff, Emanuel A. 2007. Sequence Organization in Interaction: A Primer in Conversation Analysis. Cambridge: Cambridge University Press.

Steensig, Jakob. 2013. Conversation analysis and affiliation and alignment. Carol A. Chappelle (red.), The Encyclopedia of Applied Linguistics, 944-948. Oxford, UK: Wiley-Blackwell.

Steensig, Jakob. 2015. Konversationsanalyse. Brinkmann, Svend \& Lisbeth Tanggaard (red.), Kvalitative metoder og tilgange. 2. ed. Hans Reitzels Forlag.

Steffensen, Sune V. \& Alwin Fil. 2014. Ecolinguistics: the state of the art and future horizons. Language Sciences 41(A). 6-25.

Steffensen, Sune V. 2015. Distributed Language and Dialogism: notes on non-locality, sensemaking and interactivity. Language Sciences 50. 105-19.

Stivers, Tanya \& Jack Sidnell. 2005. Introduction: Multimodal interaction. Semiotica 156(1/4). $1-20$.

Stivers, Tanya. 2008. Stance, Alignment, and Affiliation During Storytelling: When Nodding Is a Token of Affiliation. Research on Language and Social Interaction 41(1). 31-57.

Streeck, Jürgen, Charles Goodwin \& Curtis LeBaron. 2011. Embodied Interaction: Language and Body in the Material World. Cambridge. Cambridge: Cambridge University Press.

Svennevig, Jan. 2003. Echo Answers in Native/Non-Native Interaction. Pragmatics 13(2). 
Svennevig, Jan. 2010. Pre-Empting Reference Problems in Conversation. Language in Society 39(02). 173-202.

Thibault, Paul J. 2011. First-Order Languaging Dynamics and Second-Order Language: The Distributed Language View. Ecological Psychology 23(3). 210-45.

Tomasello, Michael \& Malinda Carpenter. 2007. Shared Intentionality. Developmental Science 10(1). 121-5.

Vance, Mike \& Diane Deacon. 1995. Think out of the box. Franklin Lakes, NJ: Career Press.

Wittgenstein, Ludwig. 1953. Philosophical investigations. Blackwell. 